\title{
Constructions Parameters Updating of Protecting Apron Under Deepening of Vertical Shafts
}

\author{
Pershin Vladimir V. ${ }^{1}$, Kopyitov Aleksandr I. ${ }^{1}$, Voitov Mikhail D. ${ }^{1}$, \\ Wetti Akhmed A. ${ }^{1}$, Zhuk Ivan V. ${ }^{2}$

\section{Department of Underground Construction and Mining T.F. Gorbachov Kkuzbass State Technical University, 650000 Kemerovo, Russia 2.Llc "Sibgorkompleks - Engineering" 654066 Novokuznetsk, Russia}

\begin{abstract}
New construction wedge safety shelves are offered. The principle of work engineering construction, its advantage and economic expedience of introduction in production are described.
\end{abstract}

Keywords: shaft, depending, safety shelves.

The Gornaya-Shoriya branch of Joint Stock Company "Evrazruda" is located in Tashtagol area of the Kemerovo region in the village Sheregesh, the company develops by means of underground method the Sheregesh iron ore deposit and performs the initial concentration of ores. Mining was started in 1953.

The deposit was excavated by six vertical shafts of various purposes. "Skipovoy", "Novo-Kletevoy" shafts are located on the Western flange; "Glavnyiy", "Vostochnyiy", "Lesoperepusknoy" shafts are located on the East flange; and in the center there is "Vozduhovyidayuschiy" shaft. To develop field reserves and increase the productive capacity of the mine, the institute "Sibgiproruda" realized the project of reconstruction of the mining enterprise. The important step of this project is skip shaft deepening (Fig. 1).

"Skipovoy" shaft is put down to the level of $+115 \mathrm{~m}$, inside diameter is $6,5 \mathrm{~m}$. It is designed to ore and rock mass hoisting from the mine. It is equipped with two skips, carrying capacity of which is 50 tons and two skips with carrying capacity of 15 tons. Since the shaft is productive, the deepening was conducted from advanced borehole.

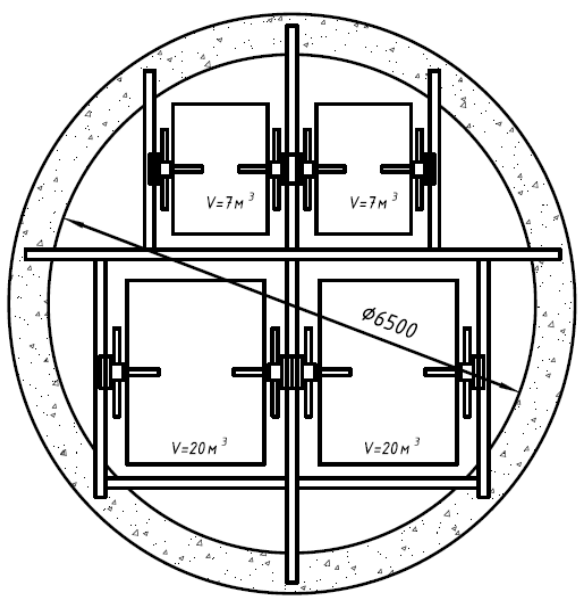

Fig. 1: "Skipovoy" shaft section

According to mine safety decisions under simultaneous shaft deepening and permanent stationary hoist, the face of deepening shaft area should be isolated from the stationary hoist by means of protective device, which must meets the following requirements:

- high protection reliability of deepening areas of vertical shafts from all kinds of accidents, associated with the fall of heavy bodies in the shaft during the lifetime of the deepening works;

- minimum construction period and the subsequent development of the sollars, as they affect directly the duration of shaft deepening and construction of new levels.

In connection with the developing of ex- 
isting levels of "Sheregeshskaya" mine for development and preparation of underlying levels, "Skipovoy" shaft must be deepened from $+115 \mathrm{~m}$. to $-85 \mathrm{~m}$. Full stop of the enterprise for the time of drivage, erection and shaft equipment could result in the loss of production capacity of the mine ore extraction and mass job cuts. In this regard, after scientific literature analysis, analysis of existing methods of shafts deepening and types of safety devices analysis, the staff of CUF and $\mathrm{M}$ department of T. F. Gorbachev KuzSTU together with specialists from the design organization LLC "Sibgorkompleks engineering" developed and implemented a new design of protective device (Fig. 2). The apron is represented by two parts, shifted in elevation, each of which has an inclined baffle wall 1,2 , dampening element 3,4 , the buffer distributive - weighting concrete plate 5,6 , horizontal support beams 7,8 .

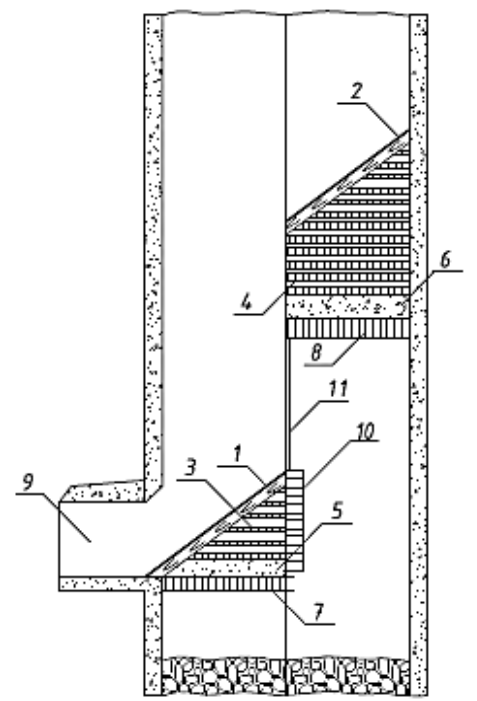

1, 2 - inclined baffle wall; 3, 4 - dampening element; 5, 6 - distributive - weighting concrete plate; 7, 8 - horizontal supporting beams;

9 - baffle stable hole; 10 - vertical wall of supporting beams; 11 - divide wall.

Fig. 2 : Wedge-type protecting apron (The Russian Federation Patent №120706)
Inclined baffle surface 1 of apron bottom is included in the baffle stable hole 9, and a series of support beams 10 forms a vertical wall, holding the elements of bottom of the device from the displacement to the shaft center. The baffle wall 11 connects the two parts of the apron, thereby blocking the section completely ${ }^{[1]}$.

The upper part of the structure is designed for high impact load and is built up under the section of ore skips and lower part is built up under the section of a smaller in size rock skips.

A wedge protecting apron works in the following way. Inevitable spile, and sometimes the whole mass of the ore skip falls on a metal sheet of inclined surface 2 , it rolls down the inclined surface 1 and enters the stable hole 9. Spile from the rock skips falls on inclined surface 1 of the apron bottom and also is accumulated in the baffle stable hole 9 .

Because of the fact that the impact load from the direction change is ten times less than the complete extinction of the kinetic energy of falling bodies, it is transmitted through the damping element on buffer distributive-weighting concrete plate, and then it is transmitted partially to the support beams, to the barrel walls in the upper part of the protective apron and to the vertical wall from the support beams 10.

In order to reduce material and labor costs, shortening installation and dismantling period the same group of authors developed a design of a bottom of the wedge protective apron, being built under the rock skips section (Fig. 3), which includes an upper inclined surface 1 from the metal sheet, buffer distributive weighting concrete plate 2, 3 dampening chock and also is laid on the bearing beam 4 , stable hole 5 and vertical divide wall 6 at the shaft axis ${ }^{[2]}$.

The difference is that a buffer plate 2 , a dampening chock 3 and supporting beams 
4 are arranged in the surface, parallel to the upper inclined surface 1.

This wedge protecting apron works in the following way. Rock spile from a vehicle falls on upper inclined surface 1 and rolls down in to a stable hole 5 , and is removed from it.

The application of the proposed design of the protecting apron according to the Gornaya-Shoriya branch of Joint Stock Company "Evrazruda" experts allowed achieving the following technical and economic indicators:

- the complexity of installation and removal of the protecting apron is reduced;

- working time on the construction of the apron is reduced to 23 days in comparison with the planned period;

- by reducing material consumption the economic efficiency in the amount of 400 thousand rubles is achieved;

- the uninterrupted duty of hoist and thereby the real profit of the company is increased of 68 million rubles;

- the stable work of the enterprise is provided until 2050.

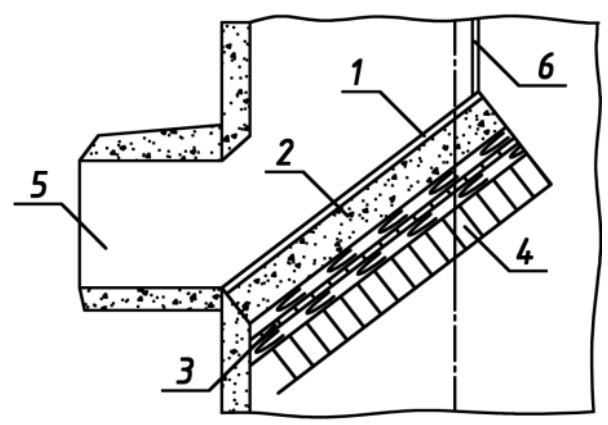

1- upper flaring wall; 2 - buffer distributive weighting concrete plate; 3 - dampening element; 4 - supporting beams; 5 - stable hole; 6 divide wall

Fig. 3: Wedge protecting apron (The Russian Federation Patent №133198)

The experience of operation of protecting aprons in the reconstruction process of the Gornaya-Shoriya branch of Joint Stock Company "Evrazruda" will improve the previously proposed design of the protective device (Fig. 4). It also is consisted of two parts, shifted in elevation, but turned around each other by $180^{\circ}$, the parts have the same inclined baffle surface 1 and 2 , the dampening element 3 and 4 , buffer distributive weighting concrete plate 5,6 disposed on the horizontal support beams $7,8^{[3]}$.

Inclined baffle surface 1,2 are included in the stable hole 9,10 , and the series of supporting beams 11,12 forms a vertical walls, retaining the elements of the apron from the shift to the center of the shaft. The divide wall 13 is formed over the top of the apron and the divide wall 14 connects two parts of the apron.

Similarly, upper part of the structure is designed for high impact load and is built up under the section of ore skips and a lower part is built up under the section of smaller in size rock skips.

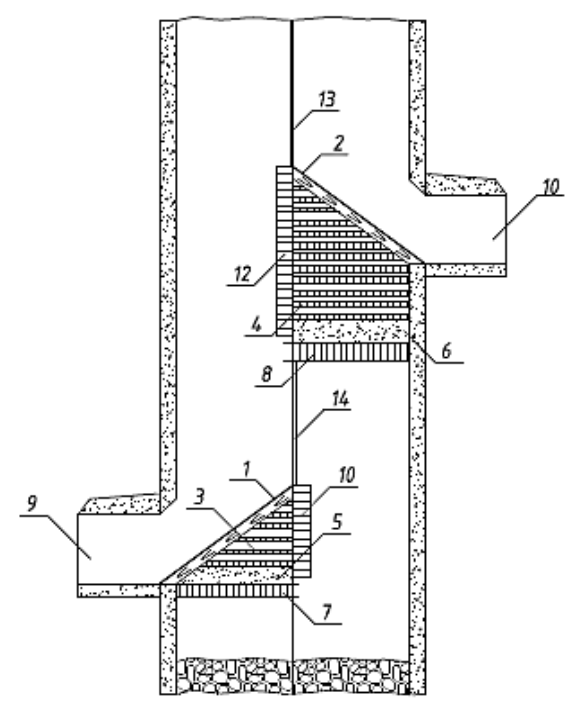

1, 2 - inclined baffle surface; 3, 4 - dampening element; 5, 6 - distributive - weighting concrete plate; 7, 8 - horizontal supporting beams; 9, 10 - stable hole; 11,12 - vertical walls consist from supporting beams; 13, 14 - divide wall

Fig. 4: Wedge protecting apron (The Russian Federation Patent №139338)

The operation principle of the apron has not changed, namely, the inevitable spile 
also falls on the appropriate inclined surface 1 or 2 and rolls into additional stable hole 10 or stable hole 9 , it is removed from them without mixing. The divide walls 13,14 prevent the rock spile enter the deepening part of the shaft.

The location of the upper part of the apron is determined by the removal conditions of the ore spile on the level of rock loading.

In the operation of protecting apron an important fact of rock mass splash in stable hole, the amount of which reaches up to $40 \mathrm{~m}^{3}$ per day, became obvious. The proposed design of the protecting apron allows dividing ore and rock spile; this will reduce the ore losses and will increase profitability of engineering structures.

\section{References:}

[1] Utility model patent № 120706 «Wedge protecting apron under deepening of vertical shafts» Authors: Kopyitov A.I., Zhuk I.V., Voitov M.D., Morozov S. S. Applied for 26.04.12 Published 29.07.2012. Bulletin №27

[2] Utility model patent № 133198 «Wedge protecting apron» Authors: Zhuk I.V., Kopyitov A.I., Pershin V.V., Voitov M.D., Wetti A. A. Applied for 06.05.13 Published 10.10.13. Bulletin №28

[3] Utility model patent № 139338 «Wedge protecting apron» Authors: Kopyitov A.I., Voitov M.D., Wetti A. A. Applied for 28.11.2013 Published 14.03.2014. Bulletin №10 